
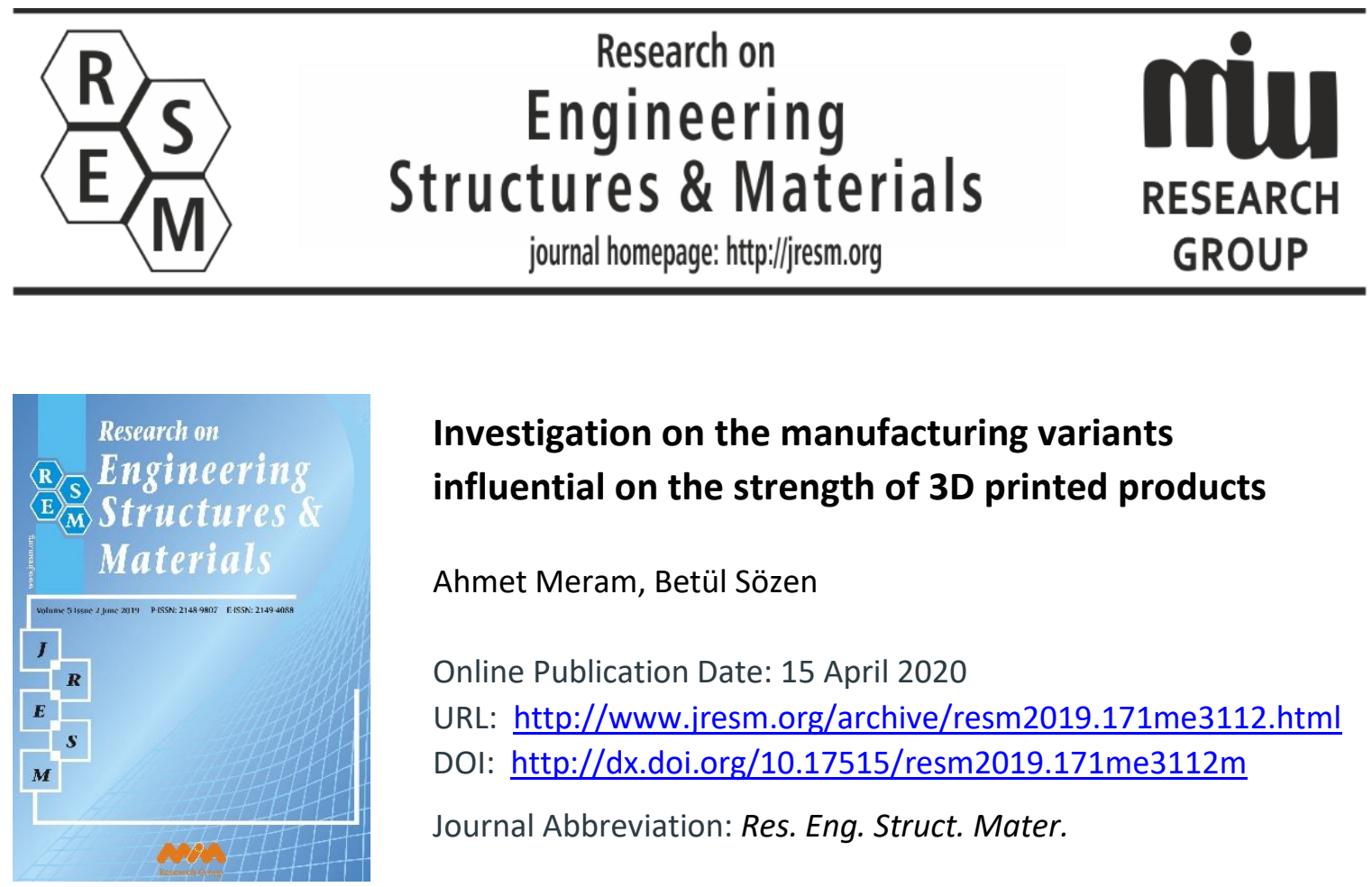

\title{
Investigation on the manufacturing variants influential on the strength of 3D printed products
}

\author{
Ahmet Meram, Betül Sözen \\ Online Publication Date: 15 April 2020 \\ URL: http://www.jresm.org/archive/resm2019.171me3112.html \\ DOI: http://dx.doi.org/10.17515/resm2019.171me3112m \\ Journal Abbreviation: Res. Eng. Struct. Mater.
}

\section{To cite this article}

Meram A, Sozen B. Investigation on the manufacturing variants influential on the strength of 3D printed products. Res. Eng. Struct. Mater., 2020; 6(4): 293-313.

\section{Disclaimer}

All the opinions and statements expressed in the papers are on the responsibility of author(s) and are not to be regarded as those of the journal of Research on Engineering Structures and Materials (RESM) organization or related parties. The publishers make no warranty, explicit or implied, or make any representation with respect to the contents of any article will be complete or accurate or up to date. The accuracy of any instructions, equations, or other information should be independently verified. The publisher and related parties shall not be liable for any loss, actions, claims, proceedings, demand or costs or damages whatsoever or howsoever caused arising directly or indirectly in connection with use of the information given in the journal or related means.

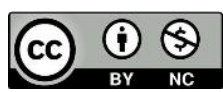

Published articles are freely available to users under the terms of Creative Commons Attribution - NonCommercial 4.0 International Public License, as currently displayed at here (the "CC BY - NC"). 


\title{
Research on Engineering Structures \& Materials
}

journal homepage: http://jresm.org

Review Article

\section{Investigation on the manufacturing variants influential on the strength of 3D printed products}

\author{
Ahmet Meram ${ }^{1, a,}$, Betül Sözen ${ }^{2, b}$ \\ ${ }^{1}$ Department of Mechatronics Engineering, KTO Karatay University, Konya/Turkey \\ ${ }^{2}$ Department of Mechanical Engineering, Selçuk University, Akșehir/Konya, Turkey
}

\begin{tabular}{|c|c|}
\hline Article Info & Abstract \\
\hline $\begin{array}{l}\text { Keywords: } \\
\text { 3D Printer; } \\
\text { Manufacturing } \\
\text { Variants; } \\
\text { Tensile Strength; } \\
\text { Additive Manufacturing }\end{array}$ & $\begin{array}{l}\text { This paper investigates the manufacturing variants influential on the strength of } \\
\text { 3D printed products. In contrast to the traditional manufacturing methods } \\
\text { which produce the final product via removing materials from parts, in 3D } \\
\text { printing technology the products are provided with adding layer by layer } \\
\text { directly from a digital file. 3D printing technology due to overcoming the many } \\
\text { difficulties and limitations of conventional fabrication approaches is a rapidly } \\
\text { progressing technology which takes attention in many industries such as } \\
\text { aerospace, automotive, medical and building industries. This paper aims to } \\
\text { research the variants affecting the mechanical properties of components } \\
\text { produced by 3D printing technologies. To reach this aim a comprehensive review } \\
\text { was conducted to determine the various process and geometric parameters in } \\
\text { 3D printing technologies. The conducted literature survey results indicate that } \\
\text { besides the filament material, the nozzle speed and diameter, layer thickness, } \\
\text { filament diameter, printing raster angle, printing pattern, temperature and infill } \\
\text { density are parameters which influence the final product quality and mechanical } \\
\text { properties in term of ultimate tensile strength, yield stress and elasticity } \\
\text { modulus. It is concluded that 3D printing filament materials strength has direct } \\
\text { affect on the strength of final product. By providing the adequate thermal } \\
\text { behavior of the system, the cohesion between layers can be improved. } \\
\text { Extrusion speed affects surface roughness and quality of the produced } \\
\text { components. Nozzle diameter has a significant influence on interlayer cohesion. } \\
\text { The honeycomb pattern due to facilitating the load transfer between layers } \\
\text { provides higher mechanical strength. Findings of this study will guide the } \\
\text { researchers and manufacturers to select appropriate printing parameters to } \\
\text { produce component with optimum mechanical properties. }\end{array}$ \\
\hline
\end{tabular}

C) 2019 MIM Research Group. All rights reserved.

\section{Introduction}

Additive manufacturing (AM), commonly known as 3D printing or rapid manufacturing (RM) [1] is a rapidly progressing technology in recent years. AM is different from traditional or subtractive manufacturing. The product is provided with adding layers until the last layer is completed while in traditional manufacturing desired product can be obtained via removing materials from parts [2-5]. 3D printing technology due to overcoming the many difficulties and limitations of conventional fabrication approaches takes attention in many industries such as aerospace, automotive, medical, building industries, fashion and fashion accessories [6-8]. This technology allows fabricating complex structures in a controllable manner with desired architecture and porosity, enables designers and engineers to create unique products that can be manufactured at

\footnotetext{
${ }^{*}$ Corresponding author: ahmet.meram@karatay.edu.tr

a orcid.org/0000-0002-8440-8462; b orcid.org/0000-0002-7011-0948

DOI: http://dx.doi.org/10.17515/resm2019.171me3112

Res. Eng. Struct. Mat. Vol. 6 Iss. 4 (2020) 293-313
} 
low volumes in an economical way [9-11] and provides advantages such as less waste, freedom of design and automation, saving of material and energy, environmental/ecological advantages [12-15]. For instance, CFM International's LEAP aircraft engine can be given an example as the first step of the additive manufacturing journey in the aviation industry [16-18].

For the first time, this engine features an additively manufactured fuel nozzle. This part used to be made up of 20 different parts. Thanks to additive manufacturing, it is now manufactured in one single piece [19-20]. In the aviation industry, materials are manufactured with highly engineered techniques, therefore these materials are generally expensive. For example, in 1 LEAP engine, there are 19 nozzles. Thanks to AM, lighter parts with lower cost and lower operational time can be produced. So via additive manufacturing, cost effectiveness in manufacturing can be provided [21].

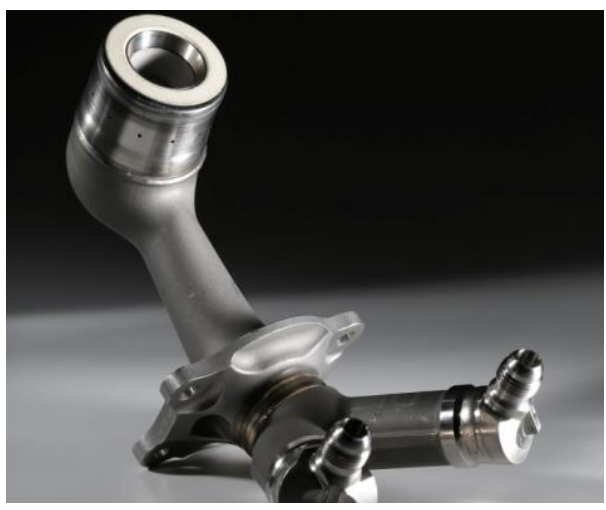

Fig. 13D-printed fuel nozzle for the LEAP engine [7]

Due to the evolution of traditional manufacturing technologies, nowadays, small scale 3D printing devices can be found in local production workshops. The additive manufacturing method is performed through various technologies, which each one requires a special 3D printing device. The most open source 3D printers are operating based on the fused deposition modeling (FDM) technology [22-25]. The 3D printing device that use FDM technology build objects layer by layer from the very bottom up by heating and extruding thermoplastic filament. Firstly, special software "cuts" CAD model into layers and calculates the way printer's extruder would build each layer. Along to thermoplastic a printer can extrude support materials as well. Then the printer heats thermoplastic till its melting point and extrudes it throughout nozzle onto base, which can also be called a build platform or a table, along the calculated path [26-28]. A computer of the $3 \mathrm{~d}$ printer translates the dimensions of an object into $\mathrm{X}, \mathrm{Y}$ and $\mathrm{Z}$ coordinates and controls that the nozzle and the base follow calculated path during printing. To support upper layer the printer may place underneath special material that can be dissolved after printing is completed [29-30]. The most common of those are acrylonitrile butadiene styrene (ABS) and poly(lactic acid)(PLA) filaments. The FDM is widely useful to produce end-use products, particularly small, detailed parts and specialized manufacturing tools [31].

The main component of a FDM machine are: extrusion head, building platform and material spool (or filament). The main parts of extrusion head are: drive wheels, heating element and extrusion nozzle. Usually, the FDM extrusion head is operating in the $x-y$ plane, while the building platform moves down in the z-plane to accommodate the deposit layers until the whole 3D part is finished [32]. In this technology as shown in Fig. 2 the raw material in the filament form feed the printing device by a mechanical mechanism and the 
raw material heated up to the to $1^{\circ} \mathrm{C}$ above its melting point, so it solidifies right after extrusion and then welds to previous layers. The desired component is fabricated by adding a raw material layer by layer in 3D printing device from three-dimensional model data. Recent FDM system heads include two nozzles; one for the part material and one for the support material. Between different additive manufacturing methods, FDM has an advantage over the others as the use of material in filament form offers flexibility and reduces the resident time in the melting chamber. In general, the FDM process is quite simple since the filament will push by the roller to the melting chamber. Print quality and sensitivity have increased with the development of 3D printing technologies. In AM technologies, environmental factors such as temperature, internal flow, and structural factors such as vibration response are critical parameters that affect as physical and thermal effects on printing hardware [32-35].

To fabricate a product using FDM technology, it is required to define a certain number of printing parameters. Since the mechanical performance and geometrical accuracy of the final product are highly affected by these parameters, the researchers conducted studies to determine the influential parameters. Kim et al. [36] experimentally investigated the effect of infill rate, orientation angle, and type of materials on the mechanical properties of specimens made ABS and PLA. Kuznetsov et al. [37] by conducting experimental tests concluded that in addition to the strength of the filament material, the strength and stability of the bonds between the layers of the specimens are highly influenced by the printing parameters. Sagias et al. [38] proposed a new approach to evaluate how the printing parameters affect the mechanical properties of the printed part to obtain a product with improved mechanical properties. The reasonable choice of printing parameters on 3D printers results in products with high strength and quality [39].

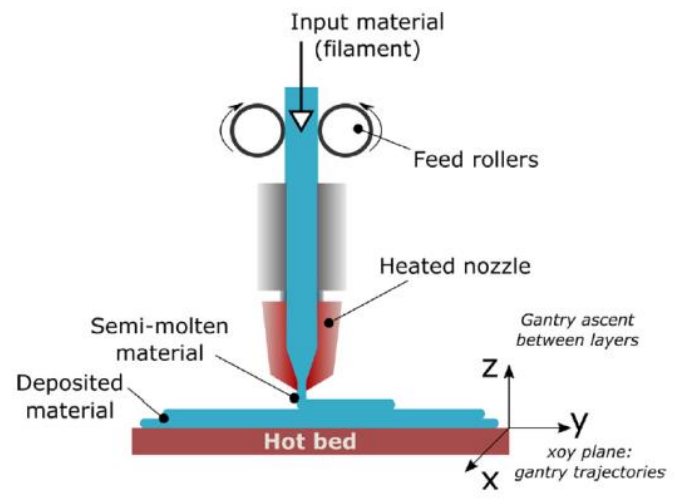

Fig.2 Schematic representation of a fused deposition modeling system [30]

The strength of the products fabricated by the 3D print device is lower than the ones made of the same polymer by injection molding [40]. Since the printing parameters are defined before producing the physical models, by understanding the role of each parameter, the mechanical performance of the final product can be improved. Motivated by this fact, this paper aims to research the parameters affecting the mechanical properties of components produced by 3D printing technologies. To reach this aim a comprehensive review was conducted to determine the various process and geometric parameters in 3D printing technologies. The conducted literature survey results indicate that besides the filament material, the nozzle speed and diameter, layer thickness, filament diameter, printing raster angle, printing pattern, temperature and infill density are parameters which influence the final product quality and mechanical properties in terms of tensile strength, yield stress 
and elasticity modulus. In addition to these parameters, road width and air gap also play a significant role in mechanical performance of FDM parts.
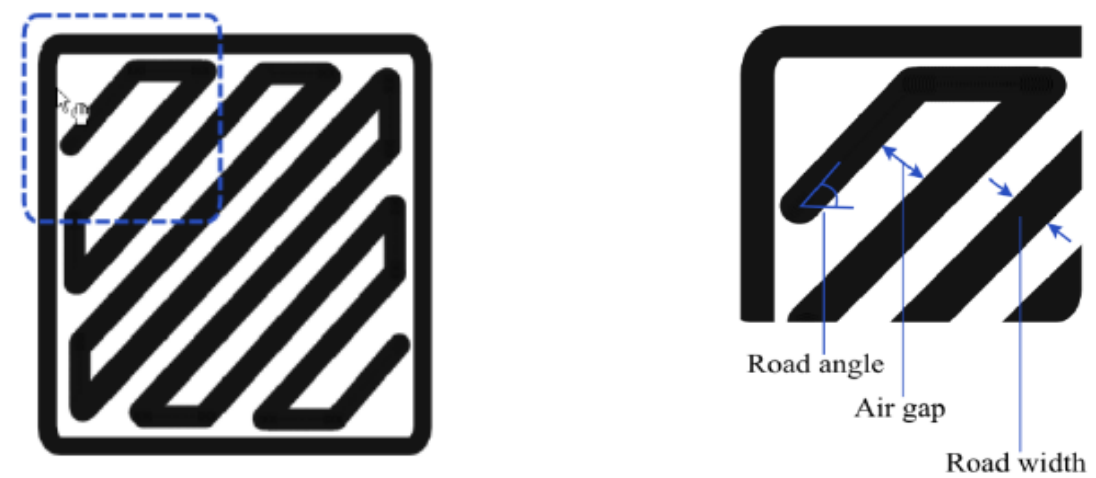

Fig. 3 Representation of the main process parameters [29]

\section{3D printer manufacturing variants}

\subsection{D Printing Filament Materials}

The filament material is one of the major parameters for determining the mechanical properties of final product. Metals, polymers, ceramics, concrete and composites are currently used in 3D printing. A wide range of polymeric materials given in Table 1 are used in 3D printers. Despite this variety, ABS and PLA are the main polymers used in the majority of applications. The main advantages of PLA to other polymers used in 3D printers are the low level of shrinkage and relatively low melting temperature. The products made of PLA due to less internal stresses have better mechanical characteristics. Tymrak et al. [39] experimentally measured the mean tensile strength values of $56.6 \mathrm{MPa}$ and $28.5 \mathrm{MPa}$ and mean elasticity modulus of $3.37 \mathrm{GPa}$ and $1.81 \mathrm{GPa}$ in specimens made of PLA and ABS, respectively. The mechanical properties of some common polymeric filament material for 3D printing given by the manufacturers are shown in Table 1. Generally, the specifications listed in Table 1 are higher than the measured values [41]. One of the main reasons of this mismatch can be explained by unparalleled testing force vector with the filament printed direction. Advanced metals are used in the aerospace and automotive industries. The ceramics and concrete are mainly employed in the manufacturing of scaffolds and building by $3 \mathrm{D}$ printing technology, respectively.

Table 1. Material abbreviations and specifications as provided by the manufacturers [41]

\begin{tabular}{|c|c|c|c|c|}
\hline Abbreviation & Full Name & $\begin{array}{c}\text { Young's } \\
\text { Modulus } \\
{[\mathrm{GPa}]}\end{array}$ & $\begin{array}{l}\text { Yield } \\
\text { Stress } \\
{[\mathrm{MPa}]}\end{array}$ & $\begin{array}{c}\text { Strain at } \\
\text { Break } \\
{[\%]}\end{array}$ \\
\hline PLA & Polylactide & 3.5 & 60 & - \\
\hline ABS & $\begin{array}{l}\text { Acrylnitril-Butadien-Styrol- } \\
\text { Copolymer }\end{array}$ & 2 & 44 & - \\
\hline PLA-H & Polylactide-Holz & 3.3 & 46 & - \\
\hline PET-C & $\begin{array}{l}\text { Polyethylenterephthalat- } \\
\text { Carbon }\end{array}$ & 3.8 & 52.5 & 8 \\
\hline PET & Polyethylenterephthalat & 3.8 & 50 & 20 \\
\hline PA-C & Polyamide-Carbon & 2.15 & 100 & - \\
\hline $\mathrm{PA}$ & Polyamide (Nylon (r)) & - & 45.6 & 34 \\
\hline
\end{tabular}


In addition to above-mentioned materials, carbon-fiber and glass-fiber reinforced composite filament materials are used in 3D printing devices. Justo et al. [42] experimentally tested specimens printed from the reinforced endless carbon-fiber reinforced filaments with a high ratio of carbon and measured the ultimate stress values of $700 \mathrm{MPa}$. In another reported study, the processability of glass fiber-reinforced ABS composites with three different glass fiber proportions was examined. The results proved that glass fiber could significantly advance the tensile strength and surface rigidity of the specimens made of ABS filament [43]. Also, the experimental investigation on the mechanical properties of thermoplastic matrix Carbon Fiber Reinforced Polymer (CFRP) composites Fused Deposition Modelling (FDM)-printed specimens proved that the carbon fiber with various ratio and length is effective in improving the mechanical properties of specimens [44]. So, besides various and geometric parameters which will be explained in detail in below, adding reinforcement material can be a method to improve mechanical properties of material which is produced using FDM technology.

\subsection{Temperature}

The extrusion temperature and bed temperature are parameters affecting the quality of finished product in 3D printing technologies due to changing the adhesion process between layers. The appropriate printing conditions in terms of temperature, depending on the used filament are provided by manufacturers.

Table 2. Thermal specification of PLA and ABS which is given by manufacturer [45]

\begin{tabular}{ccc}
\hline Thermal Properties & PLA & ABS \\
\hline Melt Flow Index & $10.3 \mathrm{~cm} 3 / 10 \mathrm{~min}$. & $9.7 \mathrm{~cm} 3 / 10 \mathrm{~min}$. \\
Glass Transition & $60-65^{\circ} \mathrm{C}$ & $105^{\circ} \mathrm{C}$ \\
Temperature & & \\
Slumping Temperature & $70-80^{\circ} \mathrm{C}$ & $110-125^{\circ} \mathrm{C}$ \\
Melting Temperature & $160-190^{\circ} \mathrm{C}$ & $210-240^{\circ} \mathrm{C}$ \\
Printing Temperature & $190-220^{\circ} \mathrm{C}$ & $230-250^{\circ} \mathrm{C}$ \\
Printbed Temperature & $50-70^{\circ} \mathrm{C}$ & $80-120^{\circ} \mathrm{C}$ \\
\hline
\end{tabular}

The type of printer is also determining in the optimum temperature of nozzle. The nozzle temperature affects the tensile strength of the specimen [46]. The experimental investigation conducted in [47] and [48] regarding extrusion temperature, proved as the temperature increases the bonding between layers improves. Fernandes et al [35] examined the mechanical properties of standard specimens made of PLA filaments in $200^{\circ} \mathrm{C}$ and $220^{\circ} \mathrm{C}$ extrusion temperatures. They obtained higher ultimate tensile stress, yield stress and elastic modulus in $220^{\circ} \mathrm{C}$ in comparison to $200^{\circ} \mathrm{C}$ extrusion temperature. They explained that by increasing the temperature the material viscosity decreased and the circular section of extruded material became oval. So, the contact area between the layers extended. By providing the adequate thermal behavior of the system, the cohesion between layers can be improved. Therefore, the freshly extruded material is able to combine chemically to the already deposited material [49].

On the other hand, when relationship between fusion temperature and dimensional accuracy is analyzed, low temperature means minimum dimensional error. According to Demircioglu et al.'s study, samples which have same printing parameters were manufactured with five different extruder temperatures $\left(185,195,205,215\right.$ and $\left.220^{\circ} \mathrm{C}\right)$. The results showed that the minimum dimensional error was obtained from the fusion temperature of $185^{\circ} \mathrm{C}$ with the value of $0.290797 \mathrm{~mm}$ and percentage of $3 \%$ and maximum dimensional error was obtained from the fusion temperature of $220^{\circ} \mathrm{C}$ with the value of $0.487134 \mathrm{~mm}$ and percentage of $4.8 \%$ [32]. 


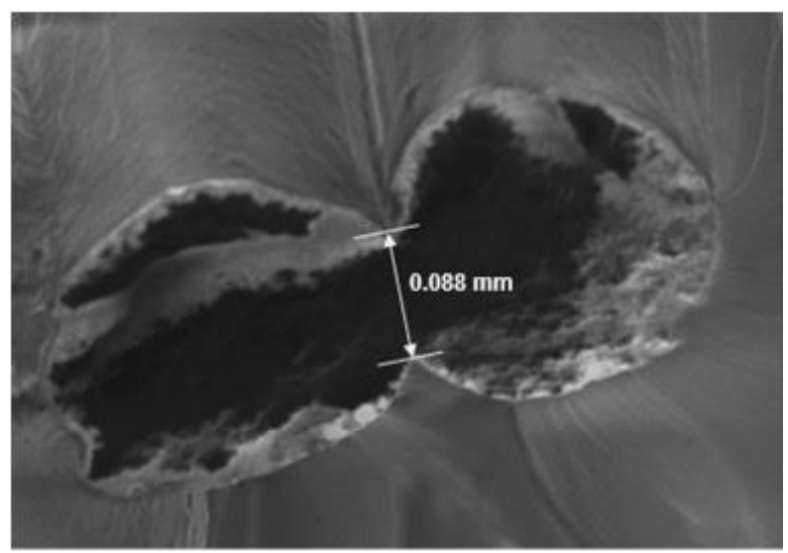

(a)

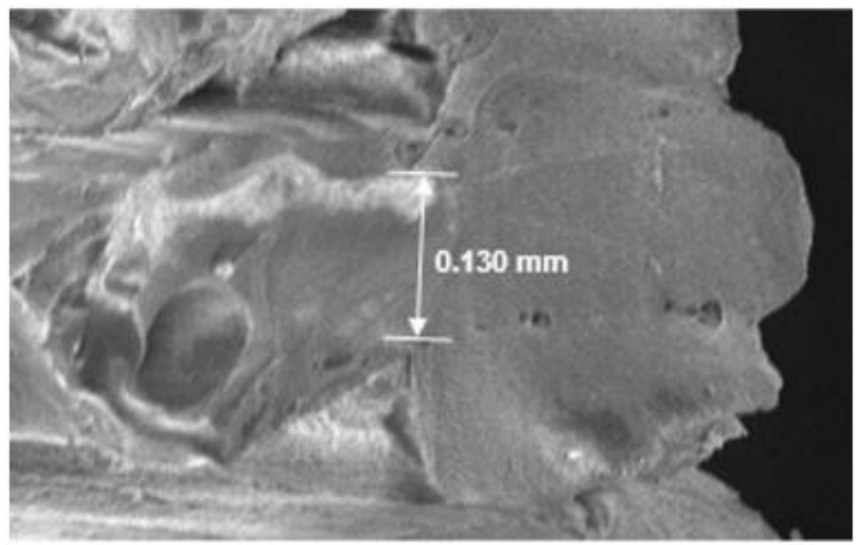

(b)

Fig. 4 SEM images of the neck formed (a) at $245^{\circ} \mathrm{C}$ extrusion temperature (b) at $260^{\circ} \mathrm{C}$ extrusion temperature [50]

\subsection{Extrusion Speed}

Extrusion speed affects surface roughness and quality of the produced components with AM technique. In Demircioglu et. al.'s study, effect of extrusion speed and surface roughness and product quality were investigated. According to study, some printing parameters were selected like below:

Layer height was selected 200 microns for all samples. The heated bed temperature was selected as $60^{\circ}$ to increase the bonding and surface quality. Extruder temperature was set to $195^{\circ} \mathrm{C}$. The samples were produced with extrusion speeds of 20,40 and $60 \mathrm{~mm} / \mathrm{s}$ to determine the surface roughness and quality. During printing, temperature, infill density, heated bed temperature, number of shell and layer thickness was set to fixed values in order to observe the effect of extrusion speed on surface roughness. As a result of study, it is observed that increasing in extrusion speed causes increasing in surface roughness [32].

\subsection{Nozzle}

The nozzle which has controllable diameter and speed influences the quality of the printed part and the productivity of the process [51]. Generally, raw materials are produced in 
1.75-mm and 3-mm diameter filaments, and nozzle diameters are varying from 0.1 to 1 $\mathrm{mm}[30]$.

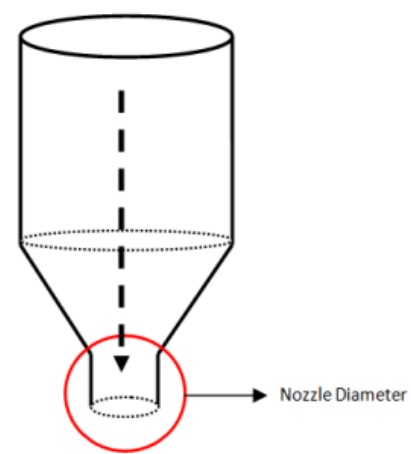

Fig. 5 Image of nozzle diameter [33]

Kuznetsov et al. 2018 [37] showed that an increase in the nozzle diameter not only reduces printing time, but also increases sample strength. Nozzle diameter has a significant influence on interlayer cohesion. Given constant layer height, printing with a larger nozzle resulted in increased strength. The advantages of larger nozzles became even more evident with greater layer thickness.

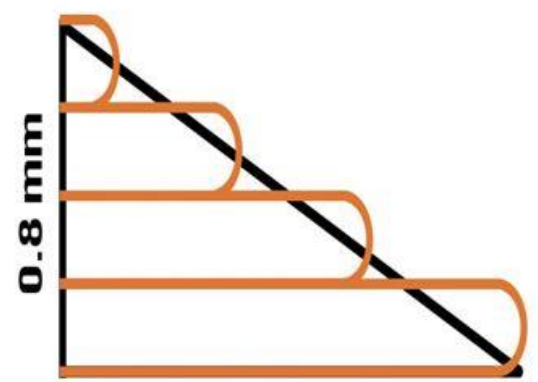

$0.2 \mathrm{~mm}$ layers

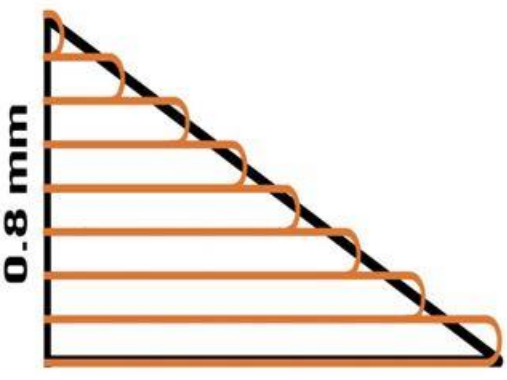

$0.1 \mathrm{~mm}$ layers

Fig. 6 Products which have different layer thickness can be printed by same nozzle diameter [52]

To determine effect of nozzle diameter, Sukındar [33] conducted a study. In this study 0.2 $\mathrm{mm}$ and $0.3 \mathrm{~mm}$ nozzle diameters were used and samples were printed. The difference of finished products can be observed by referring to Figure 8 and Figure 9 below. It is observed that the $0.3 \mathrm{~mm}$ nozzle diameter is more consistent in providing than the $0.2 \mathrm{~mm}$ nozzle diameter. It is estimated that finished product of $0.2 \mathrm{~mm}$ nozzle diameter should have better mechanical properties because of thin layers but it is inconsistent, which can also be seen from the side of the parts. Main reason of this matter can be explained as pressure drop caused by different nozzle diameters does affect the road width which in turn affects the accuracy of the finished parts. 


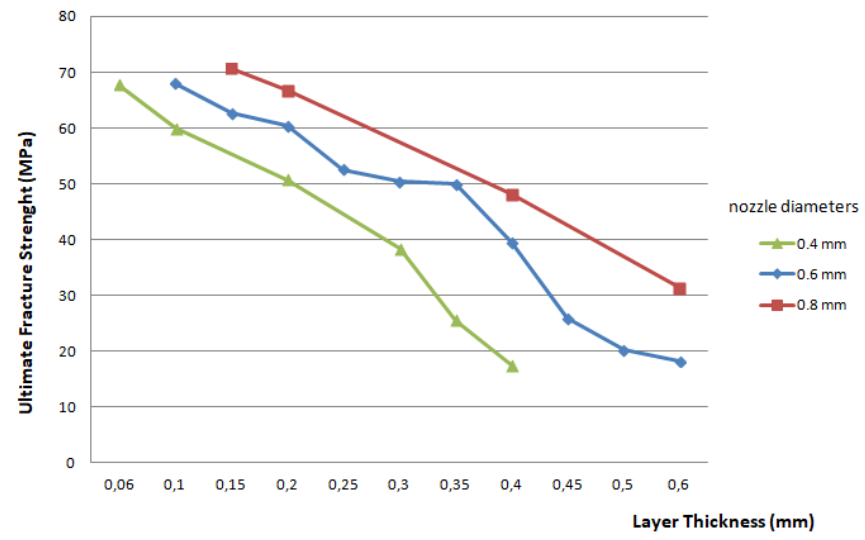

Fig. 7 Experimental data on the influence of geometrical parameters of 3D printing (nozzle diameter and layer thickness) on fabricated components' strength [37]

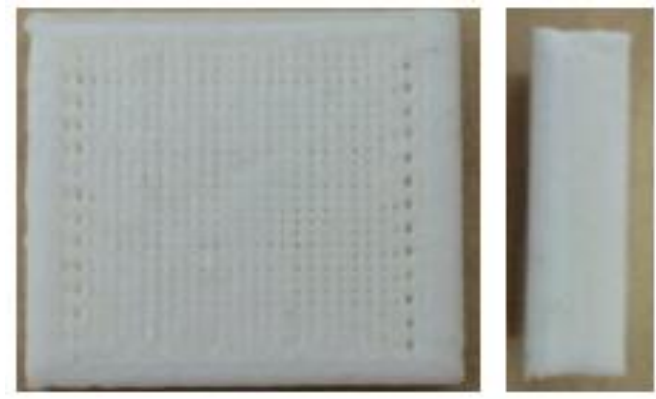

Fig. 8 Consistent road width printed by the $0.3 \mathrm{~mm}$ nozzle diameter [33]
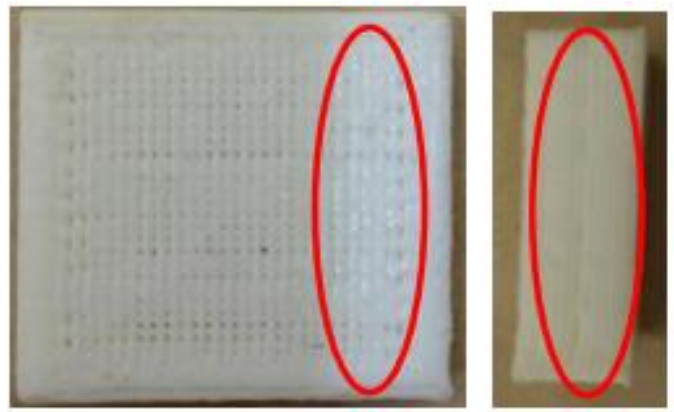

Fig. 9 Inconsistent road width printed by the $0.2 \mathrm{~mm}$ nozzle diameter [33]

\subsection{Raster Angle}

The angle between the path of the nozzle and the $\mathrm{X}$-axis of the printing platform is known as raster angle which can be selected $0^{\circ}$ to $90^{\circ}$ [53].

Raster angle is one of the major parameters affecting the mechanical strength and geometric accuracy of components fabricated by 3D printed technologies. Depending on the angle of the filaments relative to the direction of the force applied, the distribution of stress in the filaments will be different. When the filaments are in parallel by applied force, a pure tensile stress state appears. In other orientation a mix of tensile stress and shear stress are happened. That is because the best results of the ultimate tensile stress, yield 
stress and elasticity modulus were observed for a raster angle of $0^{\circ} / 90^{\circ}$ [35]. In the most of studies investigating the effect of different parameters on the strength of FDM technologies the mechanical properties are tested on flat samples oriented horizontally during the printing process [37]. Letcher and Waytashek [55] showed that the mechanical properties such as the ultimate tensile strength can be improved by exchanging the raster angle of specimens made of PLA

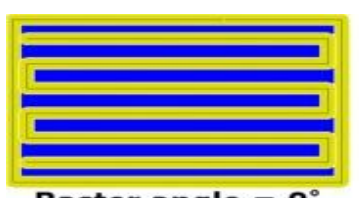

Raster angle $=\mathbf{0}^{\circ}$

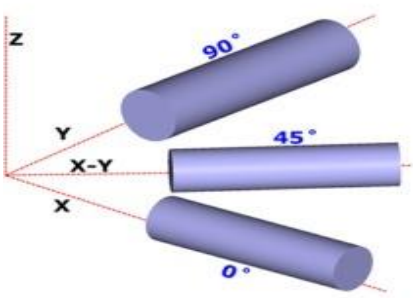

Build orientations

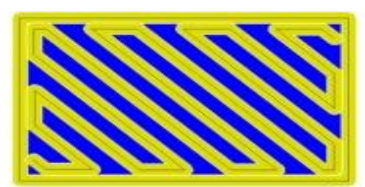

Raster angle $=45^{\circ}$

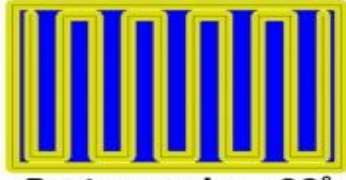

Raster angle $=90^{\circ}$

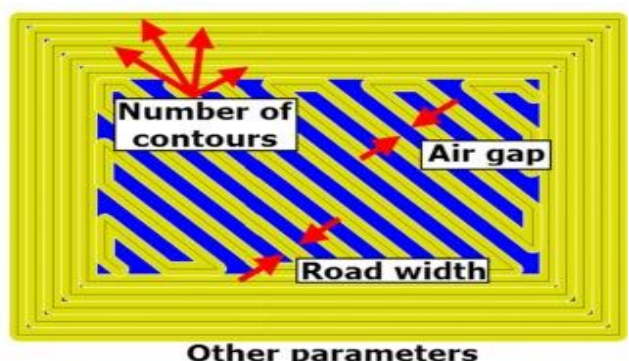

Other parameters

Fig.10 Raster angles [54]

According to Montero et al.'s [56] results of study, strength values of producing of material with various raster angles via fused deposition modeling and injection molded material is given in Fig.11 and Fig.12.

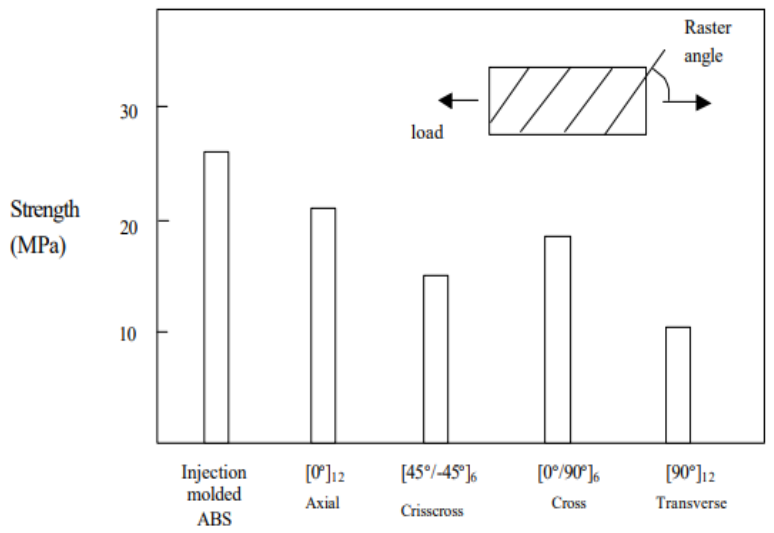

Fig. 11 Strength of specimens with various raster (-0.003 air gap) compared with injection molded ABS P400 [56]

According to another experimental study Sood et al. [47] small raster angles are not preferable because they will cause long raster. Because of this stress accumulation will increase the along the direction of deposition resulting in more distortion and hence weak bonding. But there is also an advantage of small raster angle. It means that raster is inclined along the direction of loading and will offer more resistance thus strength will improve. 


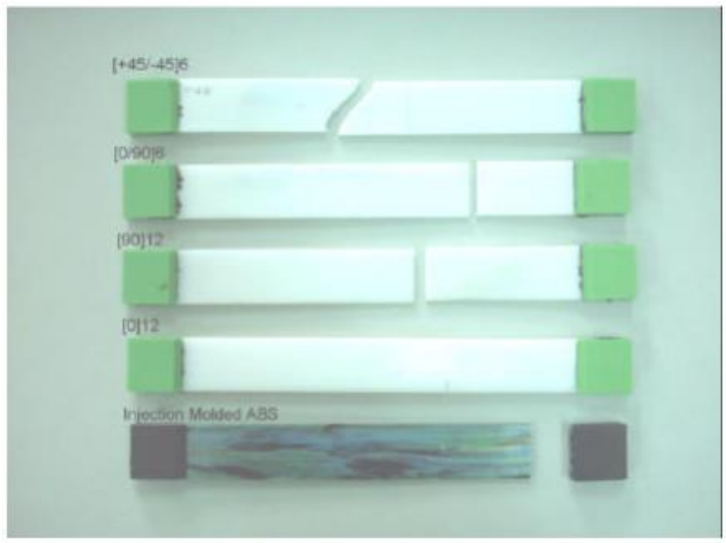

Fig. 12 Failure modes of the specimens with various raster orientations [56]

\subsection{Layer Thickness}

The most important parameter that affects surface roughness is layer thickness. Low layer thickness ensures better adhesion between layers. In Fernandes et al. reported study, in the specimens with low layer thickness $(0.1 \mathrm{~mm})$ the highest ultimate strength and yield stress values were obtained [35]. To explain this matter, the interfaces between the layers must be analyzed. Earlier studies on these interfaces prove that they are morphologically very similar to weld or knit lines in injection-molded parts. In spite of this, the mechanical strength of 3D printed components is lower than that of homogeneous products made of the same material [37-57]. The diameter of the nozzle is a major determining parameter in the minimum layer thickness. For instance, for the Ultimaker 2 machine with $0.4-\mathrm{mm}$ nozzle the minimum layer thickness proposed by the printer manufacturer was $0.06 \mathrm{~mm}$. The thicker layers are used to complete the image and practically are achievable up to the $80 \%$ of nozzle diameter [37]. SEM images of specimens with different layer thickness; relatively small and relatively large layer thickness is shown in Fig. 13.
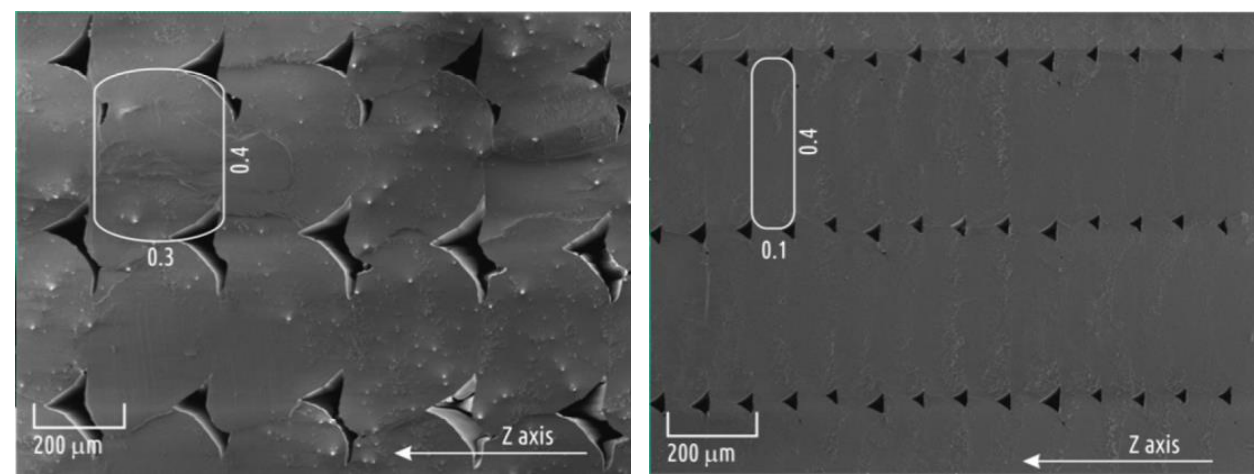

Fig. 13 The SEM images of specimens with different layer thickness: relatively large (top) and relatively small (bottom) layer thickness [37]

Once again Kuznetsov et al [37], to explain the relationship between layer height and part strength conducted experimental study. According to study layer height had the greatest influence on intra-layer cohesion. When layer height was increased for all type of nozzle $(0.4,0.6$, and $0.8 \mathrm{~mm})$, part strength decreased. For the samples under study, the decrease of strength when changing layer height from minimum to maximum was about 3.5 times. 
In addition, layer thickness is directly related to manufacturing cost, as layer thickness increases printing time decreases.

\subsection{Printing pattern and infill density}

3D printers utilize various infill patterns as shown in Fig. 14 and infill patterns known as, line, grid, concentric, cubic, triangles, octagram spiral, hectilinear, archimedianchord, tetrahedral, honeycomb and zigzag, hilburt curve, etc. The most important parameter that affects material strength is infill density. The conducted studies findings proved that the infill density percentage influences the mechanical properties printing accuracy of the finished [58]. Yah et al. [59] showed that the line pattern, especially in tensile properties performed better than rectilinear. The printing pattern in addition to mechanical properties affects the printing time and material usage. The results of Patel's study proved that the concentric infill pattern in comparison to the line and grid infill patterns had the fastest printing time. The tensile strength of specimens produced by the line infill pattern was higher than the ones produced by grid and the concentric infill pattern [60]. The results obtained in Fernandez-Vicente et al. [61] showed that the effect of the various printing pattern in maximum tensile strength is less than $5 \%$. The honeycomb pattern due to facilitating the load transfer between layers provides higher mechanical strength [62].

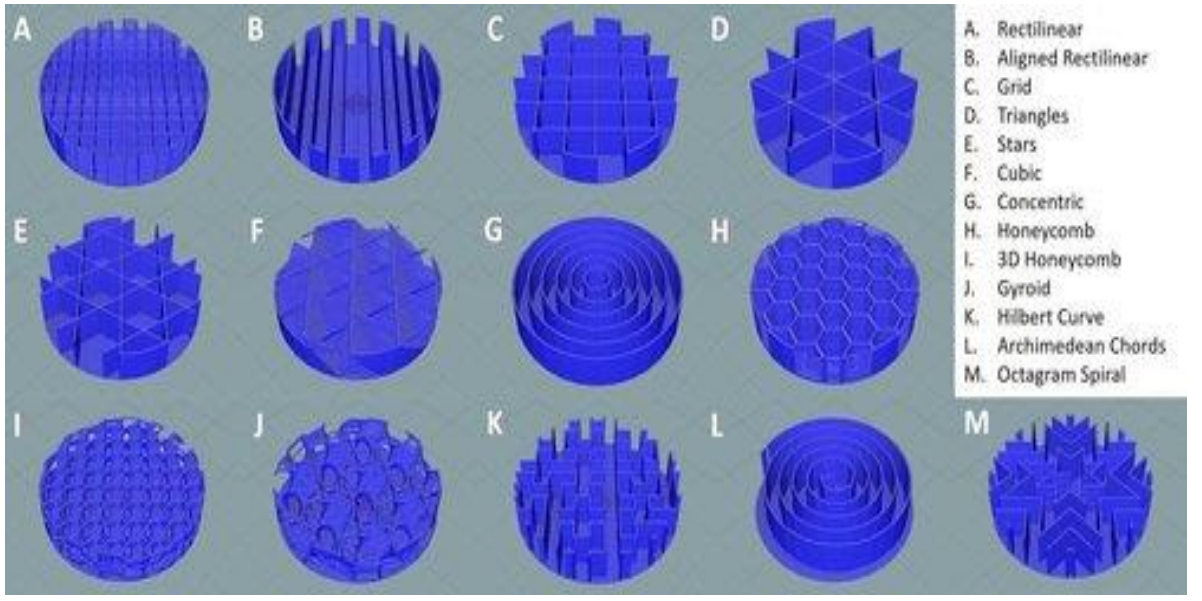

Fig. 14 Different types of printing pattern [63]

Printing parameter such as the internal infill density and pattern affect the mechanical behavior of porous products [64-65]. The increase in infill density causes an increase in tensile and compressive strength. In the improvement of mechanical strength of 3D printed products, the infill density is more effective than the printing pattern [66]. Roohani et al. investigated fatigue resistance of scaffolds that have different patterns and according to study, scaffolds with hexagonal design showed highest fatigue resistance [62].

Small filling rate setting can provide reducing filament consumption, shorting printing time, increasing forming efficiency further in actual manufacturing practice. Nevertheless, too small filling rate causes adhesive strength and support insufficient. The adhesive strength of interlayers increases rapidly with filling rate. More specifically, it increases slowly before the filling rate up to $40 \%$ and after that, increases faster. Experiments show that filling rate which smaller than $20 \%$ can save filament consumption and shorten processing cycle when nonfunctional prototypes or small tensile functional prototypes are deposited [67]. 


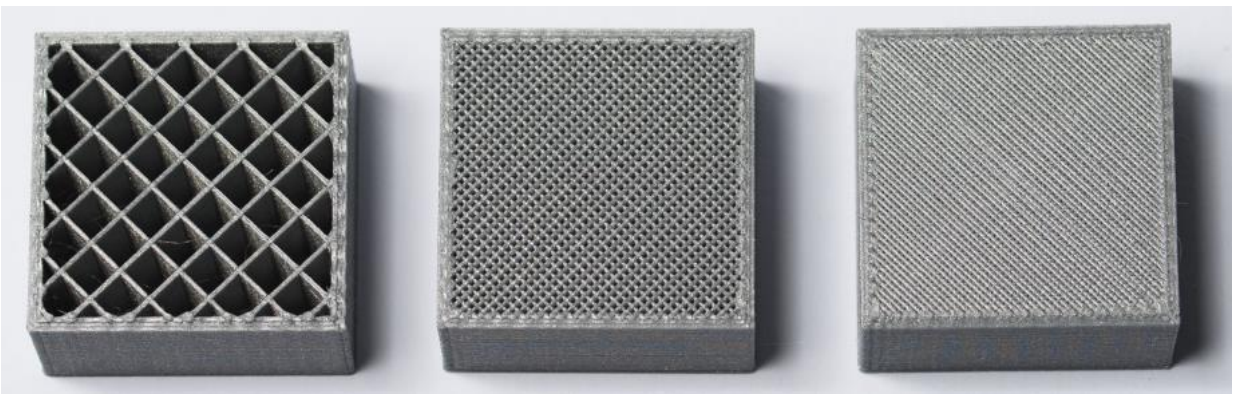

Fig.15 Various infill density used in 3D printers [66]

In addition of this, according to Kaya et. al.'s study [34], relationship between densities, infill structures and vibration are investigated. Study is carried out at three different filling rate ( $25 \%, 50 \%, 75 \%$ ) for five different manufacturing methods (Diagonal $45^{\circ} /-45^{\circ}$ (D1, D2, D3), Diagonal $60^{\circ} /-60^{\circ}$ (D4, D5, D6) , Triangular $60^{\circ} /-60^{\circ}$ ( D7, D8, D9), Wiggle (D10, D11, D12), Honeycomb $0^{\circ} / 120^{\circ} /-120^{\circ}$ ( D13, D14, D15) ).

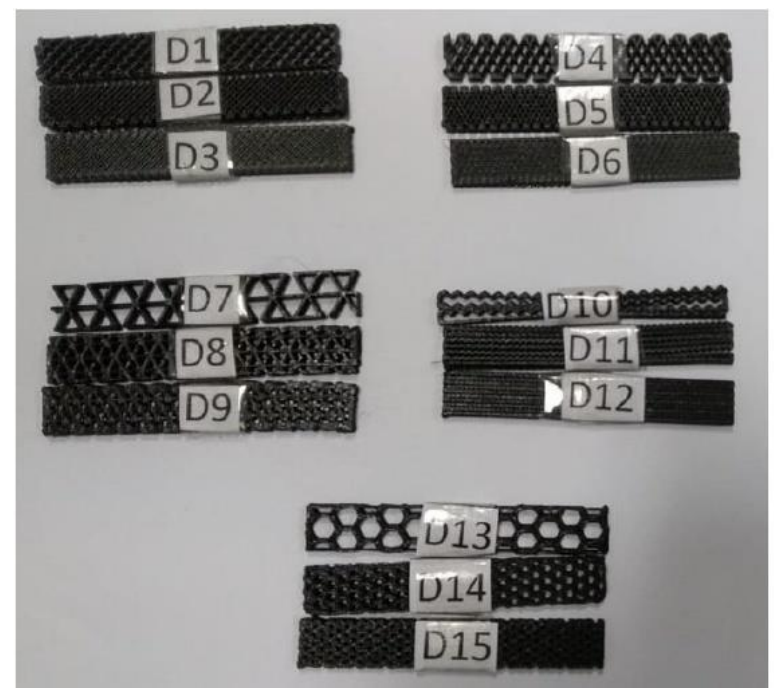

Fig.16. 3D printed samples for five different manufacturing methods [34]

As a result of Kaya et. al.'s study [34], all manufacturing methods with $50 \%$ infill ratio except honeycomb manufacturing method were determined to have the most number of vibration fluctuations. Number of vibration fluctuations occurring in manufacturing methods are interpreted according to calculated variance values. Unlike the aforementioned situation in hone honeycomb method, the increment of infilling rate causes the increase of vibration fluctuations.

When the vibrations acting on the 3D printer body are considered, the method with minimum fluctuation is observed in honeycomb structure with \%25 infill ratio (D13). Besides that, maximum fluctuation is found in wiggle structure with $\% 75$ infill ratio (D12). Furthermore, minimum mean vibration amplitude is seen to be occurred that in honeycomb structure with $\% 25$ infill ratio (D13). In addition, test results are revealed that 
maximum mean vibration amplitude is wiggle structure with \%75 infill ratio (D12). The triangular method is the second most suitable method to choose when considering the fluctuations in the vibration amplitudes and the maximum amplitude.

In a different study that conducted by Akbaş et al. [68], the effect of knitting parameters on product strength was investigated experimentally in three-dimensional printer used in thermoplastic filament production. Different production parameters such as construction angle, section grid width and construction width were analyzed experimentally. Parameters for construction angle $30^{\circ}$ and $60^{\circ}$, for construction width $0,016,0,024$ and $0,032 \mathrm{~mm}$ and finally for section grid width $0,016,0,024$ and 0,032 were used. As a result, the most important parameter that affects the material strength was determined as section grid width. Second important parameter was determined as construction width and the last one was determined as construction angle. As section on grid width decreases and as construction width increases (these two parameters can be defined as infill rate), strength of material increases.

Table 3. Results of tensile test [68]

\begin{tabular}{|c|c|c|c|c|c|c|c|c|c|}
\hline \multicolumn{5}{|c|}{$30^{\circ}$ Construction (raster) angle } & \multicolumn{5}{|c|}{$60^{\circ}$ Construction (raster) angle } \\
\hline Exp. No & $\begin{array}{l}\text { Construction } \\
\text { Width }(\mathrm{mm})\end{array}$ & $\begin{array}{c}\text { Section } \\
\text { Grid } \\
\text { Width } \\
(\mathrm{mm})\end{array}$ & $\begin{array}{l}\text { Yield } \\
\text { Strength } \\
\text { (MPa) }\end{array}$ & $\begin{array}{c}\text { Tensile } \\
\text { Strength } \\
\text { (MPa) }\end{array}$ & $\begin{array}{l}\text { Exp. } \\
\text { No }\end{array}$ & $\begin{array}{l}\text { Construction } \\
\text { Width }(\mathrm{mm})\end{array}$ & $\begin{array}{l}\text { Section } \\
\text { Grid } \\
\text { Width } \\
(\mathrm{mm})\end{array}$ & $\begin{array}{l}\text { Yield } \\
\text { Strength } \\
\text { (MPa) }\end{array}$ & $\begin{array}{c}\text { Tensile } \\
\text { Strength } \\
\text { (MPa) }\end{array}$ \\
\hline D1 & & 0.016 & 23.9 & 25 & D10 & & 0.016 & 23.2 & 28.6 \\
\hline D2 & 0.016 & 0.024 & 14.5 & 15.3 & D11 & 0.016 & 0.024 & 14.8 & 17.2 \\
\hline D3 & & 0.032 & 9.4 & 10 & D12 & & 0.032 & 9.5 & 10.1 \\
\hline D4 & & 0.016 & 11 & 11.4 & D13 & & 0.016 & 10.9 & 11.5 \\
\hline D5 & 0.024 & 0.024 & 19.3 & 20.2 & D14 & 0.024 & 0.024 & 19.4 & 20.1 \\
\hline D6 & & 0.032 & 30.5 & 31.9 & D15 & & 0.032 & 30.4 & 31.7 \\
\hline D7 & & 0.016 & 31.4 & 32.3 & D16 & & 0.016 & 30.8 & 31.9 \\
\hline D8 & 0.032 & 0.024 & 23.8 & 24.6 & D17 & 0.032 & 0.024 & 23.6 & 24.7 \\
\hline D9 & & 0.032 & 12.6 & 12.9 & D18 & & 0.032 & 12.6 & 13.5 \\
\hline
\end{tabular}

In another study, Ercan et al. , investigated compression properties of sandwich panels produced by FDM. In this study, horizontal honeycomb, vertical honeycomb, horizontal truss, vertical truss, cubic and gyroid unit cell topologies were used as core of sandwich panels [69]. The unit cell sizes of these different cell topologies were $5 \mathrm{~mm} \times 5 \mathrm{~mm}$. All cellular structures were designed at $40 \%$ relative density by changing only the cell thickness. The designed cellular structures were produced by Ultimaker 3 Extended device with the same parameters and PLA material. Produced samples were tested in Shimadzu $250 \mathrm{kN}$ test device in accordance with ASTM C365. Based on the pressure tests, the maximum compressive stresses and the elastic modulus of the sandwich panels with different cores were examined and the effect of the cell topology on the compression properties was investigated.

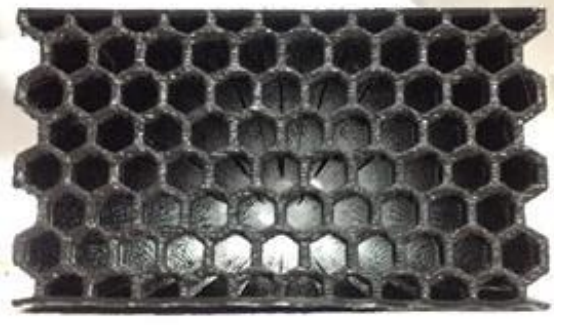

(a)

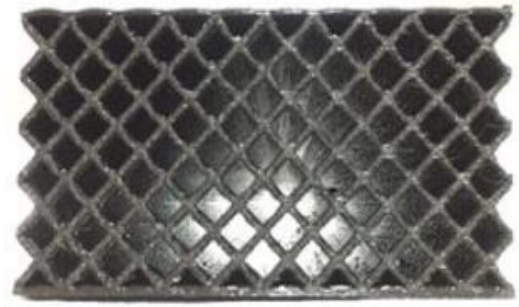

(b) 


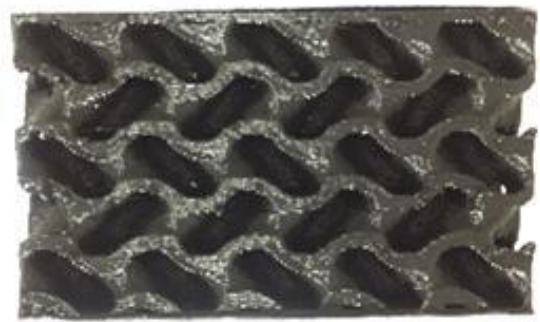

(c)

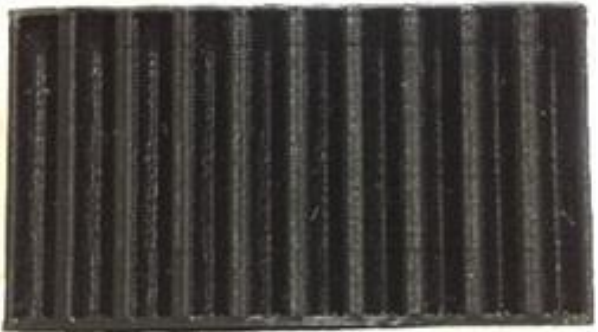

(e)

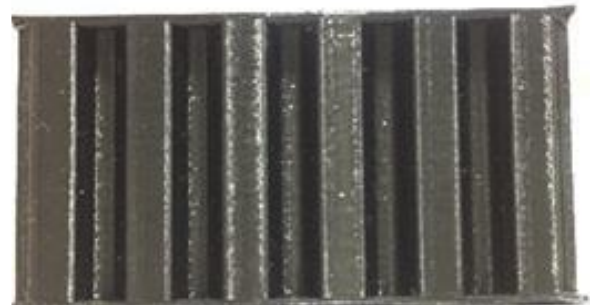

(d)

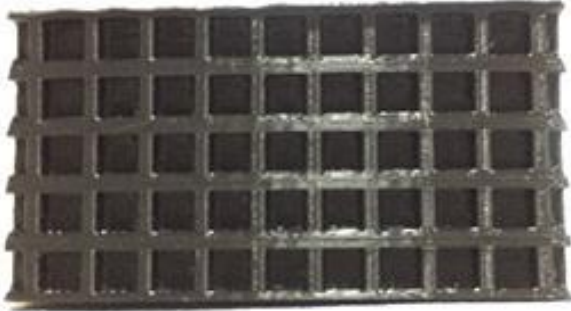

(f)

Fig. 17: Types of unit cells [69] (a) horizontal honeycomb (b) horizontal truss (c) gyroid (d) vertical honeycomb (e) vertical truss, and (f) cubic

According to experimental result of compression test, the best mechanical strength belongs to cubic unit cell with $571 \mathrm{MPa}$ value. Other unit cells that have highest strength respectively are: vertical truss, vertical honeycomb, gyroid, horizontal honeycomb and horizontal truss unit cell.

Infill types and infill density also affect hardness of manufactured components with rapid prototyping technique. In Bögrekci et al.'s study [70], some infill types like rectilinear (linear), grid (diamond) and honeycomb (hexagonal) were chosen and for each infill types; specimens were produced with the infill density values of $15,25,50,75$ and $100 \%$.

Hardness of produced specimens were measured with Emco-test DuraScan micro hardness machine. As a result hexagonal infill with density of $100 \%$ showed the highest hardness and also the hardness patterns could be presented from high to low as Hexagonal $>$ Linear > Diamond.

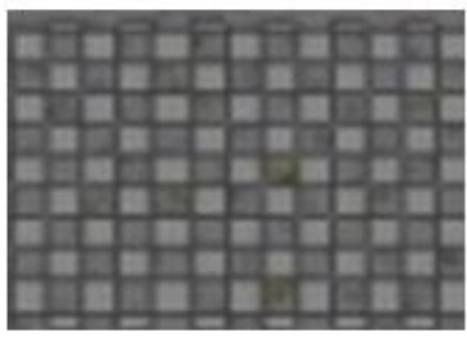

(a)

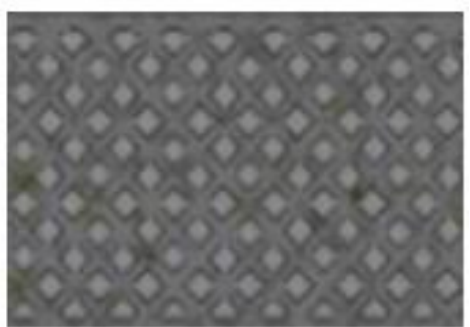

(b) 


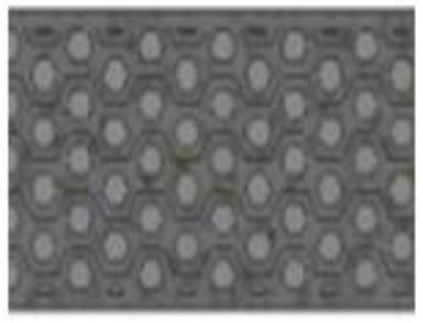

(c)

Fig. 18 Specimens with (a) Linear (b) Diamond (c) Hexagonal infill types [70]

Table 4. The obtained results from micro hardness measurements in unit of N/mm2 [68].

\begin{tabular}{cccc}
\hline Infill Rate & Hexagonal (HV) & Linear (HV) & Diamond (HV) \\
\hline $15 \%$ & 17.8 & 16.3 & 16.1 \\
$25 \%$ & 18.9 & 16.8 & 16.4 \\
$50 \%$ & 21.6 & 17.3 & 17.1 \\
$75 \%$ & 22 & 17.9 & 17.5 \\
$100 \%$ & 22.8 & 19.2 & 18 \\
\hline
\end{tabular}

As a result of Bögrekci et. al's study high level density resulted in a low amount voids and high hardness values [70].

\subsection{Air Gap}

Air gap parameter is defined as the space between the beads of deposited FDM material. Schematic representation of positive and negative gap between the deposited beads is seen Figure 19. According to Alhubail et. al's study, setting layer thickness and raster width at low level could minimize the surface roughness in addition to the air gap at $-0.01 \mathrm{~mm}$ and adjusting layer thickness and raster width at low level and the air gap at $-0.01 \mathrm{~mm}$ can provide higher tensile strength. As a result of this study, surface roughness and tensile strength of processed parts are greatly influenced by air gap parameter [71].

Falck et al. reported that the fundamental factors affecting the mechanical strength of the final part are air gap and road angle. Voids that is found in the product are source of mechanical performance reduction in FDM [29].

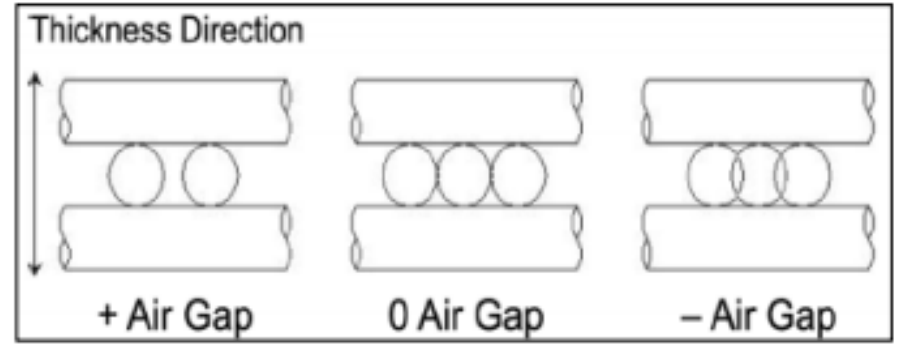

Fig. 19 Schematic representation of air gaps [71] 
Air gaps and infills determine the dimension of the contact zone between filament roads and layers, so they affect bond strength and mechanical properties of part. According to studies which have about relationship between air gap and mechanical properties, when air gap is set as negative, mechanical properties are improved [72].

\section{Conclusion}

In the present paper, a review of all effective variants on the 3D printing technology has been conducted. It is observed that the mechanical performance and geometrical accuracy of the products fabricated by 3D printing technologies are highly affected by printing parameters. Metals, polymers, ceramics, concrete and composites are currently used in 3D printing. Despite existing a wide range of polymeric materials, ABS and PLA are the main polymers used in the majority of applications. The products made of PLA due to less internal stresses and better mechanical characteristics are preferred to the products made of ABS. The high extrusion temperature decreases the material viscosity and improves the bonding between the layers. Also, by increasing the temperature the circular section of extruded material became oval. So, the contact area between the layers extended. By providing the adequate thermal behavior of the system, the cohesion between layers can be improved. Extrusion speed affects surface roughness and quality of the produced components. Nozzle diameter has a significant influence on interlayer cohesion. Given constant layer height, printing with a larger nozzle resulted in increased strength. The advantages of larger nozzles became even more evident with greater layer thickness. Depending on the angle of the filaments relative to the direction of the force applied, the distribution of stress in the filaments will be different. The maximum ultimate tensile or compression strength value is achieved when the raster angle is $0^{\circ}$. In this case, the filaments become parallel by the applied force. The printing pattern in addition to mechanical properties affects the printing time and material usage. The tensile strength of specimens produced by the line infill pattern is high in comparison to other infill patterns. The increase in infill density causes an increase in tensile and compressive strength. Air gaps and infills determine the dimension of the contact zone between filament roads and layers, so they affect bond strength and mechanical properties of part. The diameter of the nozzle is determining in the minimum layer thickness. The low layer thickness ensures better adhesion between layers and provides the high ultimate strength and yield stress values. In addition, layer thickness is directly related to manufacturing cost, as layer thickness increases printing time decreases.

\section{References}

[1] Additive Manufacturing ASTM52900 - 15.

[2] Xu T, Zhao W, Zhu J, Albanna, M, Yoo J. and Atala, A. Complex heterogeneous tissue constructs containing multiple cell types prepared by inkjet printing technology. Biomaterials, 2013: 34(1), pp.130-139. https://doi.org/10.1016/j.biomaterials.2012.09.035

[3]Kruth J. Material Incress Manufacturing by Rapid Prototyping Techniques. CIRP Annals. 1991;40(2):603-614. https://doi.org/10.1016/S0007-8506(07)61136-6

[4] Wohlers T. Tracking Global Growth in Industrial-Scale Additive Manufacturing. 3D Printing and Additive Manufacturing. 2014;1(1):2-3.

[5] Kruth J, Levy G, Klocke F, Childs T. Consolidation phenomena in laser and powder-bed based layered manufacturing. CIRP Annals. 2007;56(2):730-759. https://doi.org/10.1016/i.cirp.2007.10.004 
[6] Peres F, Martin C. Design methods applied to the selection of a rapid prototyping resource. 1999 7th IEEE International Conference on Emerging Technologies and Factory Automation Proceedings ETFA '99 (Cat No99TH8467). https://doi.org/10.1109/ETFA.1999.815386

[7] New manufacturing milestone: 30,000 additive fuel nozzles | GE Additive [Internet]. Ge.com. 2020 [cited 9 April 2020]. Available from: https://www.ge.com/additive/blog/new-manufacturing-milestone-30000-additivefuel-nozzles

[8] Bhushan B, Caspers M. An overview of additive manufacturing (3D printing) for microfabrication. Microsystem Technologies. 2017; 23(4): 1117-1124.

[9] Woesz A. Rapid Prototyping to Produce Porous Scaffolds with Controlled Architecture for Possible use in Bone Tissue Engineering. Virtual Prototyping \& Bio Manufacturing in Medical Applications. 2010:171-206. https://doi.org/10.1007/978-0-387-688312_9

[10] Salonitis K, Tsoukantas G, Stavropoulos P, Stournaras A. A critical review of stereolithography process modeling. 3rd International Conference on Advanced Research in Virtual and Rapid Prototyping, Leiria, 377-384, 2003.

[11] Pham DT., Dimov SS. Rapid Prototyping Process. Rapid Manufacturing, $1^{\text {st }}$ edition, Springer, London, 2001: 19-40, 978-1-4471-0703-3.

https://doi.org/10.1007/978-1-4471-0703-3

[12] Sood A, Ohdar R, Mahapatra S. Experimental investigation and empirical modelling of FDM process for compressive strength improvement. Journal of Advanced Research. 2012;3(1):81-90. https://doi.org/10.1016/j.jare.2011.05.001

[13] Nikzad M, Masood S, Sbarski I. Thermo-mechanical properties of a highly filled polymeric composites for Fused Deposition Modeling. Materials \& Design. 2011;32(6):3448-3456. https://doi.org/10.1016/i.matdes.2011.01.056

[14] Shen N, Chou K. Numerical thermal analysis in electron beam additive manufacturing with preheating effects. Proceedings of the 23rd annual international solid freeform fabrication symposium, Austin, 774-784, 2012. https://doi.org/10.1115/MSEC2012$\underline{7253}$

[15] Rochus P, Plesseria J.Y., Elsen,M.V., Kruth J.P., Carrus R, Dormal T. New applications of rapid prototyping and rapid manufacturing (RP/RM).ActAstronautic, 2007; 61(1-6), 352-359. https://doi.org/10.1016/i.actaastro.2007.01.004

[16] Rooks B. Rapid tooling for casting prototypes. Assembly Automation. 2002;22(1):4045. https://doi.org/10.1108/01445150210416664

[17] Patel JP, Patel CP, Patel UJ. A review on various approach for process parameter optimization of fused deposition modeling (FDM) process and Taguchi approach for optimization. International Journal of Engineering Research and Applications. 2012; 2(2):361-365.

[18] Masood SH, Rattanawong W, Iovenitti P. A generic algorithm for a best part orientation system for complex parts in rapid prototyping. Journal of Materials Processing Technology. 2003;139(1-3):110-116. https://doi.org/10.1016/S0924-0136(03)00190-0

[19] Negi S, Dhiman S, Sharma RK. Basics and applications of rapid prototyping medical models. Rapid Prototyping Journal 2014; 20(3), 256-267. https://doi.org/10.1108/RPJ-07-2012-0065

[20] Sugavaneswaran M, Arumaikkannu G. Modelling for randomly oriented multimaterial additive manufacturing component and its fabrication. Materials and Design, 2014; 54: 779-785. https://doi.org/10.1016/j.matdes.2013.08.102

[21] Saraçyakupoğlu T. The Qualification of the Additively Manufactured Parts in the Aviation Industry. American Journal of Aerospace Engineering, 2019; 6(1): 1-10. doi: $10.11648 /$ j.ajae.20190601.11 
[22] Winder J, Cooke RS, Gray J, Fannin T, Fegan T. Medical rapid prototyping and 3D CT in the manufacture of custom cranial titanium plates. Journal of Medical Engineering \&Technology, 1999; 23:26-28. https://doi.org/10.1080/030919099294401

[23] Bikas H, Stavropoulos P, Chryssolouris G. Additive manufacturing methods and modelling approaches: a critical review. The International Journal of Advanced Manufacturing Technology, 2016; 83(1-4), 389-405. https://doi.org/10.1007/s00170015-7576-2

[24] Kalita, SJ, Bose S, Hosick HL, Bandyopadhyay A. Development of controlled porosity polymer-ceramic composite scaffolds via fused deposition modeling. Materials Science and Engineering, 2003; C, 23(5): 611-620. https://doi.org/10.1016/S0928-4931(03)00052-3

[25] Ngo TD, Kashani A, Imbalzano G, Nguyen KT, Hui D. Additive manufacturing (3D printing): A review of materials, methods, applications and challenges. Composites Part B: $\quad$ Engineering, $\quad 2018 ; \quad 143: \quad 172-196$. https://doi.org/10.1016/j.compositesb.2018.02.012

[26] Singh R, Garg HK, Singh N, Hui D, Singh R, Ahuja IPS, Feo L, \& Fraternali F. Recycling of plastic solid waste: A state of art review and future applications. Composites Part B: Engineering, 2017;115: 409-422.

[27] Onder O. GE Aviation Turkey Additive Manufacturing Technologies R\&D Lab. 4 ${ }^{\text {th }}$ international congress on $3 \mathrm{~d}$ printing technologies and digital industry, Antalya, XXXVIII, 2019.

[28] Tasdelen MA, Bingöl M, Yllmaz Y, Kahramaner H. Performances of recycled thermoplastics in 3D printer. $4^{\text {th }}$ international congress on $3 \mathrm{~d}$ printing technologies and digital industry, Antalya, 182-191, 2019.

[29] Falck R, Dos Santos JF, Amancio-Filho ST. An overview on the materials and mechanical behavior used in fused deposition modeling. In 75th Annual Technical Conference and Exhibition of the Society of Plastics Engineers, SPE ANTEC Anaheim 1689-1695, 2017.

[30] Jerez-Mesa R, Gomez-Gras G, Travieso-Rodriguez JA, Garcia-Plana V. A comparative study of the thermal behavior of three different 3D printer liquefiers. Mechatronics, 2018; 56: 297-305. https://doi.org/10.1016/i.mechatronics.2017.06.008

[31] Kulkarni P, Marsan A, Dutta D. A review of process planning techniques in layered manufacturing. Rapid prototyping journal, 2000; 6(1): 18-35. https://doi.org/10.1108/13552540010309859

[32] DemircioĞlu P, Böğrekci İ, Sucuoğlu HS, Demir N. The effect of extrusion speed on surface roughness for 3D printed parts. $4^{\text {th }}$ international congress on $3 \mathrm{~d}$ printing technologies and digital industry, Antalya, 269-275, 2019.

[33] Sukindar NA, Ariffin MKA, Baharuddin, BHT, Jaafar CNA, Ismail MIS. Analyzing the effect of nozzle diameter in fused deposition modeling for extruding polylactic acid using open source 3D printing. Jurnal Teknologi, 2016; 78(10): 7-15. https://doi.org/10.11113/it.v78.6265

[34] Kaya KD, Yılmaz S, Bayramoğlu K, Göksu B. Determination of working parameters of $3 \mathrm{D}$ printers on various operation modes with different sensing systems. $4^{\text {th }}$ international congress on 3d printing technologies and digital industry, Antalya, 79-92, 2019.

[35] Fernandes J, Deus AM, Reis L, Vaz MF, Leite M. Study of the influence of 3D printing parameters on the mechanical properties of PLA. Proceedings of the 3rd International Conference on Progress in Additive Manufacturing (Pro-AM 2018), Singapore, 547-552 2018.

[36] Kim H, Park E, Kim S, Park B, Kim N, Lee S. Experimental study on mechanical properties of single-and dual-material 3D printed products. Procedia Manufacturing, 2017; 10: 887-897. https://doi.org/10.1016/j.promfg.2017.07.076 
[37] Kuznetsov VE, Solonin AN, Urzhumtsev OD, Schilling R, Tavitov AG. Strength of PLA components fabricated with fused deposition technology using a desktop 3D printer as a function of geometrical parameters of the process. Polymers, 2018; 10(3), 313. https://doi.org/10.3390/polym10030313

[38] Sagias VD, Giannakopoulos, KI, Stergiou C. Mechanical properties of 3D printed polymer specimens. Procedia Structural Integrity, 2018; 10: 85-90. https://doi.org/10.1016/j.prostr.2018.09.013

[39] Tymrak BM, Kreiger M, Pearce JM. Mechanical properties of components fabricated with open-source 3-D printers under realistic environmental conditions. Materials \& Design, 2014; 58: 242-246. https://doi.org/10.1016/i.matdes.2014.02.038

[40] Lee CS, Kim SG, Kim HJ, Ahn SH. Measurement of anisotropic compressive strength of rapid prototyping parts. Journal of materials processing technology, 2007; 187, 627630. https://doi.org/10.1016/i.jmatprotec.2006.11.095

[41] Warnung L, Estermann SJ, Reisinger A. Mechanical Properties of Fused Deposition Modeling (FDM) 3D Printing Materials. RTejournal-Fachforum für Rapid Technologien, 2018; 2018(1).

[42] Justo J, Távara L, García-Guzmán L, París F. Characterization of 3D printed long fibre reinforced composites. Composite Structures, 2018; 185: 537-548. https://doi.org/10.1016/i.compstruct.2017.11.052

[43] Zhong Li F, Zhang Z, Song L, Li Z. Short fiber reinforced composites for fused deposition modeling. Materials Science and Engineering: A, 2001; 301(2), 125-130. https://doi.org/10.1016/S0921-5093(00)01810-4

[44] Ning F, Cong W, Qiu J, Wei J, Wang S. Additive manufacturing of carbon fiber reinforced thermoplastic composites using fused deposition modeling. Composites Part B: Engineering, 2015; 80: 369-378. https://doi.org/10.1016/j.compositesb.2015.06.013

[45] (https://www.artiboyut.com/index.php/tr/bilgi-bankasi/39-3d-yazici-filamentozellikleri) Accessed 1 October 2019.

[46] Fodran E, Koch M, Menon U. Mechanical and dimensional characteristics of fused deposition modeling build styles. International Solid Freeform Fabrication Symposium, California, 419-442, 1996.

[47] Sood AK, Ohdar RK, Mahapatra SS. Parametric appraisal of mechanical property of fused deposition modelling processed parts. Materials \& Design, 2010; 31(1), 287-295. https://doi.org/10.1016/i.matdes.2009.06.016

[48] Sun Q, Rizvi GM, Bellehumeur CT, Gu P. Effect of processing conditions on the bonding quality of FDM polymer filaments. Rapid Prototyping Journal, 2008; 14(2), 72-80. https://doi.org/10.1108/13552540810862028

[49] Bellehumeur C, Li L, Sun Q, Gu P. Modeling of bond formation between polymer filaments in the fused deposition modeling process. Journal of Manufacturing Processes, 2004; 6(2), 170-178. https://doi.org/10.1016/S1526-6125(04)70071-7

[50] Bhalodi D, Zalavadiya K, Gurrala PK. Influence of temperature on polymer parts manufactured by fused deposition modeling process. Journal of the Brazilian Society of Mechanical Sciences and Engineering, 2019; 41(3), 113. https://doi.org/10.1007/s40430-019-1616-z

[51] Lanzotti A, Del Giudice DM, Lepore A, Staiano G, Martorelli M. On the geometric accuracy of RepRap open-source three-dimensional printer. Journal of Mechanical Design, 2015; 137(10), 101703. https://doi.org/10.1115/1.4031298

[52] https://blog.prusaprinters.org/everything-about-nozzles-with-a-different-diameter Accessed 2 August 2019.

[53] Wu W, Ye W, Wu Z, Geng P, Wang Y, Zhao, J. Influence of layer thickness, raster angle, deformation temperature and recovery temperature on the shape-memory effect of 
3D-printed polylactic acid samples. Materials, 2017; 10(8), 970. https://doi.org/10.3390/ma10080970

[54] Mohamed OA, Masood SH, Bhowmik JL, Somers AE. Investigation on the tribological behavior and wear mechanism of parts processed by fused deposition additive manufacturing process. Journal of Manufacturing Processes, 2017; 29: 149-159. https://doi.org/10.1016/i.jmapro.2017.07.019

[55] Letcher T, Waytashek M. Material property testing of 3D-printed specimen in PLA on an entry-level 3D printer. In ASME 2014 international mechanical engineering congress and exposition, Quebec, V02AT02A014-V02AT02A014, 2014. https://doi.org/10.1115/IMECE2014-39379

[56] Montero M, Roundy S, Odell D, Ahn SH, Wright PK. Material characterization of fused deposition modeling (FDM) ABS by designed experiments. Society of Manufacturing Engineers, 2001; 10(13552540210441166): 1-21.

[57] Kühnert I, Spörer Y, Brünig H, Tran NHA, Rudolph N. Processing of poly (lactic acid), In Industrial Applications of Poly (lactic acid), 2017: 1-33, 978-3-319-75458-1. https://doi.org/10.1007/12 201730

[58] Pei E, Melenka GW, Schofield JS, Dawson MR, Carey JP. Evaluation of dimensional accuracy and material properties of the MakerBot 3D desktop printer. Rapid Prototyping Journal, 2015; 21(5), 618-627. https://doi.org/10.1108/RPJ-09-2013-0093

[59] Aw Y, Yeoh C, Idris M, Teh P, Hamzah K, Sazali S. Effect of printing parameters on tensile, dynamic mechanical, and thermoelectric properties of FDM 3D printed CABS/ZnO composites. Materials, 2018; 466. https://doi.org/10.3390/ma11040466

[60] Patel DM. Effects of infill patterns on time, surface roughness and tensile strength in 3D printing. Int. J. Eng. Dev. Res, 2017; 5: 566-569.

[61] Fernandez-Vicente M, Calle W, Ferrandiz S, Conejero A. Effect of infill parameters on tensile mechanical behavior in desktop $3 \mathrm{~d}$ printing. $3 \mathrm{~d}$ printing and additive manufacturing, 2016, 3.3: 183-192. https://doi.org/10.1089/3dp.2015.0036

[62] Roohani-Esfahani SI, Newman P, Zreiqat H. Design and fabrication of 3D printed scaffolds with a mechanical strength comparable to cortical bone to repair large bone defects. Scientific reports, 2016; 6: 19468. https://doi.org/10.1038/srep19468

[63] https://allevi3d.com/build-with-life/infill-slic3r Accessed 5 June 2019.

[64] Sharma R, Singh R, Penna R, Fraternali F. Investigations for mechanical properties of Hap, PVC and PP based 3D porous structures obtained through biocompatible FDM filaments. Composites Part B: Engineering, 2018; 132: 237-243. https://doi.org/10.1016/j.compositesb.2017.08.021

[65] Tanikella NG, Wittbrodt B, Pearce JM. Tensile strength of commercial polymer materials for fused filament fabrication 3D printing. Additive Manufacturing, 2017, 15, 40-47. https://doi.org/10.1016/j.addma.2017.03.005

[66] Al CM, Yaman U. Improving the strength of additively manufactured objects via modified interior structure. AIP conference proceedings AIP publishing, 2017;1896 (1): 040003. https://doi.org/10.1063/1.5008029

[67] Pan AQ, Huang ZF, Guo RJ, Liu J. Effect of FDM process on adhesive strength of polylactic acid (PLA) filament. In Key Engineering Materials, 2016; 667: 181-186, Trans Tech Publications. https://doi.org/10.4028/www.scientific.net/KEM.667.181

[68] Akbas OA, Yıldız T, Sur G. Effect of construction parameters on product strength in 3D printers. $4^{\text {th }}$ international congress on $3 \mathrm{~d}$ printing technologies and digital industry, Antalya, 99-105, 2019.

[69] Ercan N, Yunus DE. Investigation compression properties of sandwich panels produced by FDM. $4^{\text {th }}$ international congress on $3 \mathrm{~d}$ printing technologies and digital industry, Antalya, 221-229, 2019. 
[70] Böğrekci İ, Demircioğlu P, Sucuoğlu HS, Turhanlar O. The effect of the infill type and density on hardness of 3D printed parts. $4^{\text {th }}$ international congress on $3 \mathrm{~d}$ printing technologies and digital industry, Antalya, 276-283, 2019.

[71] Alhubail M, Alenezi D, Aldousiri B. Taguchi-based optimisation of process parameters of fused deposition modelling for improved part quality. International Journal of Engineering Research and Technology, 2013; 2.12 : 2519.

[72] Popescu D, Zapciu A, Amza C, Baciu F, Marinescu R. FDM process parameters influence over the mechanical properties of polymer specimens: A review. Polymer Testing, 2018; 69: 157-166. https://doi.org/10.1016/i.polymertesting.2018.05.020 